\title{
Exposure and mineralogical correlates of pulmonary fibrosis in chrysotile asbestos workers
}

University of Calgary, Departments of Pathology and Community Health Sciences, Calgary, Alberta, Canada F H Y Green G Fick

University of South Carolina, Charleston, SC, USA

R Harley

National Institute for Occupational Safety and Health, Division of Respiratory Disease Studies, Morgantown, WV, USA

V Vallyathan

R Althouse

National Institute for Environmental Health Sciences, Research Triangle Park, NC, USA

J Dement

University College, Cardiff, Wales, UK

R Mitha

F Pooley

Correspondence to: Dr Francis H Y Green, Department of Pathology, University of Calgary, 3330 Hospital Drive NW, Calgary, Alberta T2N 4N1, Canada.

Francis H Y Green, Russell Harley, Val Vallyathan, Rochelle Althouse, Gordon Fick, John Dement, Ravi Mitha, Fred Pooley

\begin{abstract}
Objectives-The relation between lifetime cumulative exposure to asbestos, pathological grade of pulmonary fibrosis, and lung burden of asbestos at death, was explored in a necropsy population of former workers in a chrysotile asbestos textile plant in South Carolina.
\end{abstract}

Methods-Estimates of cumulative, mean, and peak exposures to asbestos were available for 54 workers. Necropsy records and lung tissue samples were obtained from hospital files. Matched control cases were selected from consecutive necropsies performed at the same hospitals. The extent and severity of pulmonary fibrosis was graded on tissue sections. Mineral fibres in lung tissue were characterised by transmission electron microscopy combined with $\boldsymbol{x}$ ray spectroscopy.

Results-A significant positive correlation $(r=0.67, P<0.0001)$ was found between lifetime cumulative exposure to asbestos and total lung burden of asbestos fibres. This relation was also found for the individual types of asbestos associated with the exposure: chrysotile and tremolite. Pulmonary fibrosis was correlated with both cumulative exposure to asbestos $(r=0.60, P<0.01)$ and the concentration of asbestos fibres in the lung $(r=0.62, P<$ $0.0001)$. The concentration of tremolite fibres in the lung provided a better estimate of lung fibrosis than did the concentration of chrysotile. Asbestosis was usually present in asbestos textile workers with more than 20 fibre-years cumulative exposure. The lengths and aspect ratios of chrysotile asbestos, but not amphibole asbestos, were greater in the lungs of asbestos fibre workers than in the control population. Textile workers with lung cancer had significantly greater cumulative exposures and fibrosis scores than workers without lung cancer.

Conclusions-Both cumulative exposure to asbestos and lung fibre burden are strongly correlated with severity of asbestosis. The data also support the hypothesis that the high prevalence of asbestosis and lung cancer in this population resulted from exposure to long fibres of chrysotile asbestos in the workplace.

(Occup Environ Med 1997;54:549-559)
Keywords: asbestos; chrysotile; tremolite; lung fibre burden

Asbestos exposure has been repeatedly shown to be associated with increased mortality from non-malignant respiratory diseases, lung cancer, pleural and peritoneal mesotheliomas, and in some studies, cancers of the gastrointestinal tract and larynx. ${ }^{12}$ Mortalities and severity of the disease associated with asbestos seem to vary considerably depending on the type of asbestos and the industrial setting or process where exposure occurs. ${ }^{3-5}$ The purpose of this study was to evaluate relations between pulmonary fibrosis (asbestosis) and estimates of cumulative exposure and lung burden of asbestos fibres in workers occupationally exposed to asbestos. Also, we attempted to measure the minimal levels of asbestos exposure necessary to invoke a pulmonary lesion compatible with asbestosis.

Although pulmonary fibrosis (asbestosis) was the primary focus of this study, we also documented the prevalence of pleural plaques and lung cancer in the exposed population and in a control population taken from the same geographical location. The study population was derived from a cohort of asbestos textile workers that have been previously studied epidemiologically. ${ }^{4-8}$ This population is interesting in two respects: firstly, the workers had been exposed almost exclusively to chrysotile asbestos; and secondly, the prevalence of disease associated with asbestos has been shown to be considerably increased with steep dose-response relations for risk of death from lung cancer and asbestosis. ${ }^{46}$

\section{Materials and methods}

WORKPLACE AND ESTIMATIONS OF EXPOSURE The plant under study is located in Charleston, South Carolina and began production of asbestos packing materials for steam engines and pumps in 1896. Asbestos textiles were first produced in 1909, and this remained the predominant product from the plant. Chrysotile was the only type of asbestos processed as a raw material. The raw asbestos was predominantly derived from Quebec, but chrysotile from British Columbia and Zimbabwe was also processed. A small amount of crocidolite yarn was woven into a tape or made into a braided packing beginning in the 1950 s and ending in about 1975. Crocidolite was never carded, spun, or twisted and the total quantity of crocidolite processed was extremely small $(<1000$ $\mathrm{kg}$ ). As tapes were woven with a wet process, 
exposures to crocidolite was low. By comparison, the average annual consumption of chrysotile at this factory was about three to four million $\mathrm{kg}$. The processes for production of asbestos textiles at this plant were typical of this industry and remained unchanged for the period 1940 to 1975 .

Details of the methods used to estimate asbestos exposure have been published previously. ${ }^{i}$ As individual exposure data were not available for each worker in the cohort, estimates of exposure by job category at the plant were required. Both the exposure zone concept and the uniform task concept were used to develop exposure models which used historic plant production, control, and exposure data to estimate exposure by job and calendar period. Cumulative lifetime time weighted average exposure for each worker was calculated by multiplying estimates of exposure for each job held by the time spent in each job and was expressed as fibres $>5 \mu \mathrm{m} / \mathrm{ml}^{3} \times$ years (fibre-years). Information on average exposure and peak exposure (highest average exposure for any job) was also obtained. Other factors taken into account were the latency interval (time since first employment to death), total years employed, sex, and age at death.

SELECTION OF SUBJECTS

Asbestos workers

The vital status of all people employed in textile production for at least one month (men) or six months (women) of the plant between 1 January 1940 and 31 December 1965 was followed up until 31 December 1975. Eight hundred and seventy four deaths were identified in the 3744 people in the cohort. Death certificates were obtained for all known dead workers from state records. If a necropsy was indicated on the death certificate, the necropsy protocol, formalin fixed tissues, blocks, and slides were requested from the hospital in which death occurred. Because death certificates do not always indicate whether or not a necropsy was performed, we also searched the necropsy files of the teaching hospitals in Charleston, South Carolina for additional cases. From these two sources, we identified necropsies on 87 people-about $10 \%$ of all deaths in the cohort. Pathological material was available on 59 of these. From the necropsy reports, details of the gross appearances of the lungs and pleural cavities were obtained. The materials were also reviewed for evidence of pulmonary disease that might be mistaken for asbestosis - for example, pulmonary fibrosis due to radiotherapy or chemotherapy. Five asbestos workers had major confounding diseases and were excluded from further analyses. These were: chemotherapy fibrosis (two) and radiation fibrosis (three). When these cases were excluded, tissue slides suitable for histological grading were available for 54 asbestos workers.

Control population

Slides, blocks, and tissues for the control necropsy population were obtained by matching age of death, sex, hospital of death, and year of death of the asbestos workers through com- puter matching of hospital records. Age and year of death were matched to within \pm 2 years. Thirty eight matches were obtained. Four cases were excluded because of major confounding diseases. These were sarcoidosis (one), radiation fibrosis (one), tuberculosis (one), and scleroderma (one). The personnel files of the asbestos textile plant were screened to ensure that no former employees were included in the control population. None were identified.

\section{HISTOLOGICAL ANALYSIS}

Special stains

The number of sections per subject varied. The mean (SD) number of slides for the asbestos workers and controls was 5.9 (3.8) and 1.5 $(0.7)$, respectively. The site of origin of the tissue section could not be ascertained for most cases. Likewise, the quality of the tissue sections varied considerably. A few of the lungs had been inflated with fixative; however, most had not been fixed in inflation and, thus, showed postmortem collapse. Sections stained with haematoxylin and eosin were available for all cases and controls. The following special stains were used on tissues from all subjects for which paraffin blocks or tissues were available: elastic trichrome, Perl's iron stain, and a polychrome stain developed to differentiate precollagen from collagen." The polychrome stain was useful in some cases for distinguishing terminal fibrotic processes - such as organising pneumonia and adult respiratory distress syndrome-from mature fibrosis associated with asbestos exposure.

\section{Fibrosis score}

Only slides with recognisable lung parenchyma were graded; slides consisting predominantly of tumour, bronchus, lymph nodes, abscess, or infarct were excluded. Fibrosis was graded according to criteria established by a joint National Institute for Occupational Safety and Health (NIOSH) and College of American Pathologists (CAP) Committee. "' Briefly, each slide was graded for both severity $(0-4)$ and extent (0-3), and the scores for each were multiplied to give a fibrosis score $(0-12)$ for that slide. The scores for all the slides from that particular case were averaged to give an overall fibrosis score for the subject.

Severity was graded into five categories. The most severe lesion determined the grade for each slide. Grade 0 was assigned when there was no fibrosis associated with bronchioles; grade 1 was used to describe fibrosis confined to the wall of one or more respiratory bronchioles; grade 2 was given to fibrosis of bronchiolar walls with involvement of alveolar ducts or two or more layers of alveoli; grade 3 included fibrosis as in category 2 but with coalescence of fibrotic change between two adjacent acini; and grade 4 was assigned to slides showing changes of category 3 plus architectural restructuring with cyst formation (honeycombing).

Extent was used as an index of the proportion of respiratory bronchioles involved. Grade 0 represented absence of disease; grade 1 was used when only occasional bronchioles were involved; grade 2 indicated that more than 
occasional, but less than half of all bronchioles were involved, and grade 3 was used when more than half of all bronchioles were affected by fibrosis. To ensure objectivity in grading, the slides from asbestos workers and controls were randomly mixed before grading. Thus, the observer was not made aware of whether the slide was from an asbestos worker or control at the time of grading. Each slide from both the exposed and control populations was initially graded by three pathologists independently. Grading was then reviewed and major disagreement (defined as a difference in two or more categories for either severity or extent between any two pathologists) was resolved by simultaneous review and discussion. The decision process was aided by use of the special stains. Initial scores were statistically analysed to measure variability between and within pathologists. The consensus grades were used for subsequent statistical analyses.

\section{Grading of asbestos bodies}

Asbestos bodies were graded on a scale of 0-3 with a method reported by Wagner et al. ${ }^{11}$ Each section was evaluated independently by three pathologists, under the light microscope, with a $25 \times$ objective, and assigned to one of four categories based on the number of asbestos bodies present. Asbestos bodies were recognised by their clear straight central cores and beaded ferruginous coatings. Ferruginous fragments or bodies with unusual or opaque cores were not characterised as asbestos bodies. When asbestos bodies were few or absent on sections stained with haematoxylin and eosin, iron stains were prepared and evaluated. An absence of asbestos bodies was graded 0; grade I represented one or occasional bodies found after prolonged examination; grade II represented moderate numbers of asbestos bodies; and grade III was used to describe sections with numerous, easily detected asbestos bodies. The individual scores for all slides from a case were summed and an average score for each case was obtained.

MINERALOGICAL ANALYSIS

Lung tissue suitable for mineralogical analysis was available for 39 former asbestos workers and 31 of the control population. No significant differences in demographic profile or exposure history were noted between the whole cohort of asbestos workers and the subgroup with mineralogical information. The samples from all the controls were formalin fixed wet tissue; 26 of the samples from the asbestos workers were also wet tissues and the remaining 13 samples were embedded in paraffin blocks.

Mineral fibres were extracted from the lung samples with characterised standard procedures. ${ }^{12}$ All specimens were dried to constant weight at $80^{\circ} \mathrm{C}$ (specimens received in blocks were first trimmed and deparaffinised in xylene). About $50-100 \mathrm{mg}$ of dried tissue per sample was digested in $10 \mathrm{ml}^{3} 5 \mathrm{~N}$ hot sodium hydroxide, washed, and the residue was then ashed in an oxygen atmosphere. The final extract was suspended in $10 \mathrm{ml}$ distilled water adjusted to $\mathrm{pH} 1.0$ with $\mathrm{HCI}$, sonicated, and aliquots immediately filtered on $25 \mathrm{~mm} 0.2 \mu \mathrm{m}$ pore size Nuclepore filters. All glassware was thoroughly cleaned and reagents prefiltered to reduce ambient asbestos contamination to a minimum. The filters with adherent dust were carbon coated, treated with chloroform, and carbon extraction replicas of the filter surfaces were prepared on gold electron microscope support grids. All fibrous particles with an aspect ratio greater than 3:1 were counted in randomly selected grid squares at a magnification of 20000 . Only filters showing optimal particle density were evaluated. A minimum of 100 (range 100-800) fibres were analysed by energy dispersive $x$ ray analysis and their chemical composition was used to identify the fibres. ${ }^{12}$ Particle dimensions were measured directly from the viewing screen. Selected area electron diffraction (SAED) was not routinely used for identification, but was used for confirmation of identity of some fibres. The number of mineral fibres $\times 10^{6} / \mathrm{g}$ dry lung was calculated from an algorithm with grid square density, dilution factor, and original dry weight of lung.

An analysis of counting errors, biases due to variations in fibre length and concentration, and the repeatability of the method have been published elsewhere. ${ }^{12}$ The reproducibility of the method could not be directly ascertained because of the heterogeneous nature of the distribution of dust in tissue specimens. With known quantities of asbestos dust in a simulated extraction and preparation procedure SDs varied from $20 \%$ to $40 \%$ of the mean values counted. For seven former asbestos workers, two samples from different, but unspecified, sites were analysed. Moderate variability in fibre counts was noted between sites, but the proportions by fibre type remained relatively constant. Similar variations in fibre concentration between sites in the same lung have been recorded by others. ${ }^{13}{ }^{14}$ For subsequent analyses, the mean value for the two samples was used.

To investigate any potential bias introduced by including lung fibre data derived from paraffin embedded blocks, both blocks and wet tissues were analysed from a series of cases. The variability in fibre count was similar to that found between analyses of wet tissues from different sites. Also, we compared the fibre lengths of chrysotile and tremolite with paraffin blocks of tissue extracted from the 13 cases and compared them with the data from the 26 cases with formalin fixed tissues. Mean lengths for both chrysotile and tremolite were shorter in the paraffin block group but these differences were not significant.

\section{STATISTICAL ANALYSES}

All data analyses and graphs were calculated with the S-plus data analysis system. ${ }^{15}$ Fibre concentrations and exposure variables were log normally distributed. Accordingly, geometric means are presented for these variables but medians are presented for other variables. The primary response variables were fibrosis, concentration of fibres in the lung, and exposure. 
Table 1 Population characteristics

\begin{tabular}{|c|c|c|c|c|}
\hline & \multicolumn{2}{|l|}{ Men } & \multicolumn{2}{|l|}{ Women } \\
\hline & median & (quartiles) & median & (quartiles) \\
\hline \multicolumn{5}{|l|}{ Asbestos workers: } \\
\hline Age at death & 56.0 & $(49.0-61.0)$ & 57.0 & $(55.0-63.5)$ \\
\hline Year of death & 1971 & $(1964-74)$ & 1971 & $(1967-75)$ \\
\hline Age first employed & 24.0 & $(19-28)$ & 27.0 & $(24-34)$ \\
\hline Total years employed & 9.9 & $(1.4-29.2)$ & 7.5 & $(2.6-21.5)$ \\
\hline Years latency & 30.0 & $(27.0-36.0)$ & 30.0 & $(26.5-34.3)$ \\
\hline $\begin{array}{l}\text { Interval between last employment and } \\
\text { death }(y)\end{array}$ & 16 & $(1.0-25.0)$ & 15.0 & $(6.0-23.0)$ \\
\hline \multicolumn{5}{|l|}{ Controls: } \\
\hline Age at death & 59.0 & $(49.3-62.0)$ & 62.5 & $(59.3-65.0)$ \\
\hline Year of death & 1972 & $(1967-74)$ & 1971 & $(1971-73)$ \\
\hline
\end{tabular}

There were 44 male and 10 female asbestos workers and 22 male and 12 female controls.

Scatter plots with regression lines, $P$ values, and correlation coefficients are provided to complement the analysis. Multiple linear regression analyses were used to assess the possible effect of age at death, latency, years since last exposure, peak exposure, and mean exposure on the primary response variables. ${ }^{16}$ Several regression models, including addition of a quadratic term for exposure and exploration of a threshold effect of exposure on lung fibrosis, were also developed.

\section{ASSESSMENT OF VARIABILITY BETWEEN AND} WITHIN READERS

For the assessment of variability between and within readers, 49 randomly selected slides from the study populations were reread independently by the three pathologists. The interval between the first and second readings varied but was always greater than three months, and the pathologists were not aware of the original reading or case identity. The second readings were compared with the original uncorrected readings to measure variability between and within observers for severity and extent. The data were tabulated and analysed by methods described previously. ${ }^{17}$ Pairwise reproducibility between pathologists for severity was $71 \%$ for exact agreement and $98 \%$ for agreement to \pm one category. For extent, the percentages were $69 \%$ and $97 \%$, respectively. Average pairwise reproducibility within pathologists for severity was $53 \%$ for exact agreement and $96 \%$ for agreement to \pm one category. For extent, the percentages were $62 \%$ and $96 \%$, respectively.

The $\kappa$ index was also determined. ${ }^{18}$ This statistic corrects for the proportion of agreement that would be expected by chance. With this statistic, mean (range) reproducibility between pathologists for severity was $60 \%(53 \%-72 \%)$ for exact agreement and $93 \%(89 \%-100 \%)$ for agreement to \pm one category. For extent the percentages were $50 \%(42 \%-58 \%)$ and $80 \%$ (70\%-100\%), respectively. For reproducibility within pathologists mean $\kappa$ values for severity were $36 \%(31 \%-40 \%)$ for exact agreement and $86 \%(86 \%-88 \%)$ for agreement to \pm one category. For extent the percentages were $38 \%$ $(27 \%-62 \%)$ and $82 \%(82 \%-82 \%)$, respectively.

\section{Results}

Table 1 shows the population characteristics for the control population and asbestos workers. No significant differences in mean age or year of death were noted between the asbestos worker and control populations. Men predominated in both groups. There were no significant differences for any of the population statistics between men and women. Accordingly, to achieve greater statistical power, men and women were combined for most analyses.

Smoking histories were available for nine of 55 asbestos workers and two of 34 controls. In view of the fact that many subjects in the study group died several decades ago, we did not attempt to obtain the missing information, and smoking status was not used in any of the analyses.

Table 2 presents exposure variables for the asbestos textile workers categorised by years of employment. Median (range) latency was 30.0 (17-44) years. Although workers with the longest employment tended to have longer latency intervals, there were also many workers with brief employment and long latencies. The median (range) cumulative exposure for all asbestos workers was $30.2(0.1-370.0)$ fibreyears. Cumulative exposure was positively correlated with years employed and also with peak exposure. Male workers had larger cumulative exposures than female workers-34.6 and 25.6 median fibre-years respectively. Values for the other exposure variables, peak exposure, mean exposure, and latency were similar for male and female workers.

Table 3 shows the type and number of mineral fibres in the lungs of 39 asbestos workers and 31 control cases. The values for the controls were similar to those found in other control populations analysed in this laboratory. ${ }^{19}$ Preliminary analyses showed no significant differences in the ratio of lung fibre concentration to lifetime cumulative exposure for men and women in the study population;

Table 2 Exposure variables for male and female asbestos workers

\begin{tabular}{|c|c|c|c|c|c|c|c|c|c|}
\hline \multirow{2}{*}{$\begin{array}{l}\text { Years* } \\
\text { employed }\end{array}$} & \multirow[b]{2}{*}{$n$} & \multicolumn{2}{|c|}{ Lifetime cumulative exposuret } & \multicolumn{2}{|c|}{ Peak exposureł } & \multicolumn{2}{|c|}{ Average exposure\} } & \multicolumn{2}{|c|}{ Latency } \\
\hline & & median & (quartiles) & median & (quartiles) & median & (quartiles) & median & (quartiles) \\
\hline $0.1-1.3$ & 13 & 2.4 & $(0.5-5.4)$ & 5.4 & $(3.9-8.9)$ & 4.5 & $(3.2-6.0)$ & 29.0 & $(23.3-31.0)$ \\
\hline $1.4-8.9$ & 13 & 15.8 & $(7.4-27.9)$ & 7.0 & $(4.6-10.8)$ & 5.0 & $(2.7-7.9)$ & 27.0 & $(21.0-33.0)$ \\
\hline $9.0-27.2$ & 15 & 106.0 & $(48.0-193.9)$ & 13.6 & $(7.8-24.3)$ & 4.8 & $(1.8-7.4)$ & 30.0 & $(26.0-35.0)$ \\
\hline$>27.3$ & 14 & 120.3 & $(59.0-228.1)$ & 9.6 & $(4.3-22.8)$ & 4.0 & $(1.8-7.4)$ & 36.0 & $(30.8-40.3)$ \\
\hline Total & 55 & 30.2 & $(5.8-108.6)$ & 7.9 & $(4.6-14.3)$ & 4.7 & $(3.2-7.4)$ & 30.0 & $(26.0-36.0)$ \\
\hline
\end{tabular}

$\star$ Each category equals one quartile.

†Expressed as fibres $>5 \mu \mathrm{m} / \mathrm{ml}^{3} \times$ years employed (fibre-years).

$\ddagger$ Highest mean exposure for any job (fibres $>5 \mu \mathrm{m} / \mathrm{ml}^{3}$ ).

$\oint$ Fibre-years/years of employment.

TYears from first employment to death. 
Table 3 Concentrations of mineral fibres in lung tissue

\begin{tabular}{|c|c|c|c|c|c|c|c|c|c|c|c|c|c|c|}
\hline \multirow{2}{*}{$\begin{array}{l}\text { Fibre } \\
\text { concentration } \\
\text { (fibres } \times 10^{6} / \mathrm{g}\end{array}$} & \multicolumn{2}{|c|}{ All fibres* } & \multicolumn{2}{|c|}{ Chrysotile } & \multicolumn{2}{|l|}{ Tremolite } & \multicolumn{2}{|c|}{$\begin{array}{l}\text { Amositel } \\
\text { crocidolite }\end{array}$} & \multicolumn{2}{|c|}{ Anthophyllite } & \multicolumn{2}{|l|}{ Mullite } & \multicolumn{2}{|l|}{ Othert } \\
\hline & Controls & $\begin{array}{l}\text { Asbestos } \\
\text { workers }\end{array}$ & Controls & $\begin{array}{l}\text { Asbestos } \\
\text { workers }\end{array}$ & Controls & $\begin{array}{l}\text { Asbestos } \\
\text { workers }\end{array}$ & Controls & $\begin{array}{l}\text { Asbestos } \\
\text { workers }\end{array}$ & Controls & $\begin{array}{l}\text { Asbestos } \\
\text { workers }\end{array}$ & Controls & $\begin{array}{l}\text { Asbestos } \\
\text { workers }\end{array}$ & Controls & $\begin{array}{l}\text { Asbesto } \\
\text { workers }\end{array}$ \\
\hline$<0.1$ & 0 & 0 & 0 & 0 & 48.4 & 16.7 & 64.5 & 47.6 & 87.1 & 81.0 & 3.2 & 26.2 & 9.7 & 26.2 \\
\hline $0.1<1.0$ & 0 & 0 & 0 & 0 & 41.9 & 14.3 & 22.6 & 23.8 & 6.4 & 7.1 & 6.4 & 9.5 & 16.1 & 16.7 \\
\hline $1.0<10$ & 25.8 & 14.3 & 71.0 & 14.3 & 9.7 & 26.2 & 12.9 & 21.4 & 6.4 & 11.9 & 74.2 & 42.9 & 64.5 & 50 \\
\hline $10<100$ & 74.2 & 57.1 & 29.0 & 64.3 & 0 & 42.9 & 0 & 7.1 & 0 & 0 & 16.1 & 21.4 & 9.7 & 7.1 \\
\hline $\begin{array}{l}100<1000 \\
\text { Geometric }\end{array}$ & 0 & 28.6 & 0 & 21.4 & 0 & 0 & 0 & 0 & 0 & 0 & 0 & 0 & 0 & 0 \\
\hline $\begin{array}{l}\quad \text { mean } \\
\text { (95\% CIs) } ¥ \\
\text { P values }\end{array}$ & $\begin{array}{l}16.02 \\
(2.01-5 \\
<0.0001\end{array}$ & $\begin{array}{l}52.46 \\
36)\end{array}$ & $\begin{array}{c}6.71 \\
(3.00-8 \\
<0.000\end{array}$ & 253.45 & $\begin{array}{c}0.26 \\
(5.53-30 \\
<0.0001\end{array}$ & $\begin{array}{l}3.56 \\
.27)^{3}\end{array}$ & $\begin{array}{c}0.21 \\
(1.08-4 \\
=0.031\end{array}$ & ${ }^{0.47}$ & $\begin{array}{l}0.13 \\
(0.76-1 \\
=0.43\end{array}$ & $\begin{array}{l}0.16 \\
90)^{-16}\end{array}$ & $\begin{array}{c}4.01 \\
(0.18-0 . \\
=0.027\end{array}$ & $90)^{1.63}$ & $\begin{array}{l}1.9 \\
(0.26-1 \\
=0.098\end{array}$ & 13) \\
\hline
\end{tabular}

$\star$ Data expressed as $\%$ of asbestos workers $(n=39)$ or controls $(n=31)$ within each fibre concentration category.

+ The category other includes fibres containing iron, rutile, and muscovite.

$\$ 95 \%$ CIs for ratio of geometric means.

$\oint \mathrm{P}$ values based on two sample $t$ tests on the log scale.

consequently, data from both sexes were combined for subsequent analyses.

Chrysotile asbestos was the predominant mineral fibre in the lungs of both asbestos textile workers and controls, whereas substantial values for tremolite were only found in the lungs of the asbestos textile workers. The numbers of chrysotile and tremolite fibres were much greater in the asbestos workers than in the controls $(P<0.0001)$. The geometric mean values for crocidolite and amosite fibres were also increased in the asbestos workers compared with the controls $(P<0.05)$. Twenty eight per cent of the asbestos workers and $13 \%$ of the controls had values of crocidolite or amosite in their lungs exceeding $1 \times 10^{6}$ fibres/g dry lung. The predominant non-asbestos fibrous minerals were mullite, rutile, and iron. Concentrations of mullite were significantly greater in the controls than in the lungs of the asbestos workers $(P<0.05)$.

Table 4 shows the dimensions of the asbestos fibres extracted from the lungs of the controls and the asbestos workers. In general, the lengths and aspect ratios of the amphibole asbestos fibres were similar in the two groups. By contrast, the chrysotile fibres in the lungs were considerably different between the two groups. Median length and aspect ratio for 3554 chrysotile fibres in the lungs of textile workers were $1.5 \mu \mathrm{m}$ and $23.1 \mu \mathrm{m}$ respectively, compared with $0.5 \mu \mathrm{m}$ and $7.7 \mu \mathrm{m}$ for 618 fibres analysed in the lungs of the controls.

\section{CUMULATIVE LIFETIME EXPOSURE AND LUNG} BURDEN OF ASBESTOS FIBRES

Age, latency, and years since last exposure were all considered in a regression model, but only lifetime cumulative exposure was predictive of total asbestos in the lung. Figure 1 shows graphically the relation between cumulative lifetime exposure to asbestos and total lung asbestos fibres in the men and women textile workers. A highly significant correlation was found ( $r=0.67, \mathrm{P}<0.0001)$. The regression equation for this relation was:

$\log$ asbestos fibres (fibres $\times 10^{6} / \mathrm{g}$ ) $=2.43+$ $0.405 \mathrm{log}$ (lifetime cumulative exposure (fibreyears))

Total lung tremolite and chrysotile fibres were also highly correlated with cumulative exposure $(r=0.48, \mathrm{P}<0.01$ and $r=0.55, \mathrm{P}<$ 0.01 , respectively). No relation was found between non-asbestos fibres and lifetime cumulative exposure. The mean number of asbestos bodies on tissue sections was strongly associated with lifetime cumulative exposure $(P<0.01)$, total amphibole $(P<0.01)$, and total chrysotile fibres $(P<0.05)$ in the lung.

Table 4 Size distribution of asbestos fibres in lung tissue

\begin{tabular}{|c|c|c|c|c|c|c|c|c|c|c|}
\hline \multirow[b]{2}{*}{$\begin{array}{l}\text { Fibre } \\
\text { characteristics }\end{array}$} & \multicolumn{2}{|l|}{ Chrysotile } & \multicolumn{2}{|l|}{ Tremolite } & \multicolumn{2}{|l|}{ Crocidolite } & \multicolumn{2}{|l|}{ Amosite } & \multicolumn{2}{|l|}{ Anthophyllite } \\
\hline & $\begin{array}{l}\text { Asbestos } \\
\text { workers }\end{array}$ & Controls & $\begin{array}{l}\text { Asbestos } \\
\text { workers }\end{array}$ & Controls & $\begin{array}{l}\text { Asbestos } \\
\text { workers }\end{array}$ & Controls & $\begin{array}{l}\text { Asbestos } \\
\text { workers }\end{array}$ & Controls & $\begin{array}{l}\text { Asbestos } \\
\text { workers }\end{array}$ & Controls \\
\hline \multicolumn{11}{|c|}{ Fibre length $(\mu \mathrm{m}):$} \\
\hline $\begin{array}{l}\text { Median } \\
\text { (Quartiles) }\end{array}$ & $\begin{array}{l}1.5 \\
(0.5-1.5)\end{array}$ & $\begin{array}{l}0.5 \\
(0.5-0.5)\end{array}$ & $\begin{array}{l}1.5 \\
(1.5-2.5)\end{array}$ & $\begin{array}{l}1.5 \\
(0.5-2.5)\end{array}$ & $\begin{array}{l}2.5 \\
(1.5-5.0)\end{array}$ & $\begin{array}{l}1.5 \\
(1.0-4.3)\end{array}$ & $\begin{array}{l}0.5 \\
(0.5-1.5)\end{array}$ & $\begin{array}{l}0.5 \\
(0.5-0.5)\end{array}$ & $\begin{array}{l}1.5 \\
(1.5-3.5)\end{array}$ & $\begin{array}{l}2.9 \\
(1.8-4.6)\end{array}$ \\
\hline \multicolumn{11}{|c|}{ Fibre diameter $(\mu \mathrm{m})$ : } \\
\hline $\begin{array}{l}\text { Median } \\
\text { (Quartiles) }\end{array}$ & $\begin{array}{l}0.06 \\
(0.06-0.06)\end{array}$ & $\begin{array}{l}0.06 \\
(0.06-0.06)\end{array}$ & $\begin{array}{l}0.19 \\
(0.13-0.19)\end{array}$ & $\begin{array}{l}0.19 \\
(0.07-0.32)\end{array}$ & $\begin{array}{l}0.32 \\
(0.19-0.32)\end{array}$ & $\begin{array}{l}0.19 \\
(0.07-0.25)\end{array}$ & $\begin{array}{l}0.07 \\
(0.07-0.07)\end{array}$ & $\begin{array}{l}0.07 \\
(0.07-0.16)\end{array}$ & $\begin{array}{l}0.19 \\
(0.19-0.25)\end{array}$ & $\begin{array}{l}0.32 \\
(0.27-0.32)\end{array}$ \\
\hline Aspect ratio: & & & & & & & & & & \\
\hline $\begin{array}{l}\text { Median } \\
\text { (Quartiles) }\end{array}$ & $\begin{array}{l}23.1 \\
(7.7-23.1)\end{array}$ & $\begin{array}{l}7.7 \\
(7.7-7.7)\end{array}$ & $\begin{array}{l}7.9 \\
(7.8-11.4)\end{array}$ & $\begin{array}{l}7.82 \\
(7.7-8.0)\end{array}$ & $\begin{array}{l}15.2 \\
(6.2-23.1)\end{array}$ & $\begin{array}{l}13.2 \\
(7.7-17.2)\end{array}$ & $\begin{array}{l}7.7 \\
(7.7-22.0)\end{array}$ & $\begin{array}{l}7.7 \\
(3.9-7.7)\end{array}$ & $\begin{array}{l}7.8 \\
(7.8-18.4)\end{array}$ & $\begin{array}{l}9.9 \\
(5.5-14.8)\end{array}$ \\
\hline $\begin{array}{l}\text { Number of } \\
\text { fibres } \\
\text { measured }\end{array}$ & 3354 & 618 & 989 & 29 & 128 & 42 & 341 & 4 & 14 & 7 \\
\hline $\begin{array}{l}\text { Range of fibres } \\
\text { counted } \\
\text { per case }\end{array}$ & 13-535 & $5-57$ & $1-177$ & $1-5$ & $1-31$ & $1-19$ & $1-306$ & 1 & $1-5$ & $1-3$ \\
\hline $\begin{array}{l}\text { Number of } \\
\text { samples } \\
\text { with values }\end{array}$ & 39 & 31 & 37 & 15 & 19 & 9 & 20 & 4 & 7 & 4 \\
\hline
\end{tabular}




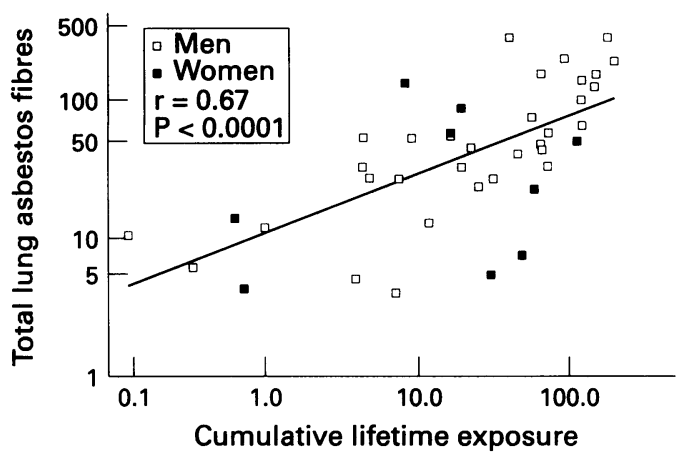

Figure 1 Plot showing relation between cumulative lifetime exposure to asbestos, expressed as fibres $>5 \mu \mathrm{m} / \mathrm{ml}^{3} \times$ number of years of exposure, and lung burden of fibres in 41 former asbestos textile workers. Total lung asbestos fibres equals the sum of commercial asbestos fibres

(chrysotile +tremolite +crocidolite) that could be attributed to exposure in the workplace. Cumulative lifetime exposure and lung burden of asbestos fibres are expressed on a log scale. The $P$ value was based on a test for non-zero slope with linear regression analysis.

\section{CUMULATIVE LIFETIME EXPOSURE AND LUNG} FIBROSIS

Figure 2 shows the relation between cumulative lifetime exposure and fibrosis score for the asbestos textile workers. There is a significant relation between the two variables $(r=0.60, \mathrm{P}<$ 0.01 ). The regression equation for this relation was:

fibrosis score $=1.01+1.24 \log$ (lifetime cumulative exposure)

Analysis weighted by the number of slides did not change the interpretation. The effect of age was additive $(P<0.05)$ with no evidence for an interaction $(P=0.36)$. The regression equation for the relation between fibrosis and lifetime cumulative exposure after adjustment for age was:

fibrosis score $=-5.0+0.96 \log$ (lifetime cumulative exposure) +0.13 (age at death)

The effect was found for both men and women asbestos workers and the magnitude of the effect was independent of the sex of the worker $(P=0.17)$. No independent effect of peak exposure, mean exposure, time since last exposure, or latency on lung fibrosis was found. When the asbestos workers were stratified by levels (quartiles) of exposure, median fibrosis scores were greater in the asbestos workers than in the control population for all levels of exposure (table 5). This was significant $(P<$ 0.001 ) for all exposure quartiles except quartile 1.

LUNG BURDEN OF ASBESTOS FIBRES AND LUNG FIBROSIS

Figure 3 shows the relations between lung burden of mineral fibres and lung fibrosis score. The regression equation for the relation between total asbestos fibre burden and fibrosis score for the asbestos workers (men+women) was:

fibrosis score $=2.02+2.32 \log$ (total asbestos fibres $)(P<0.0001)$

Multiple linear regression analysis was used to model the relation between fibrosis score and concentrations of chrysotile and tremolite

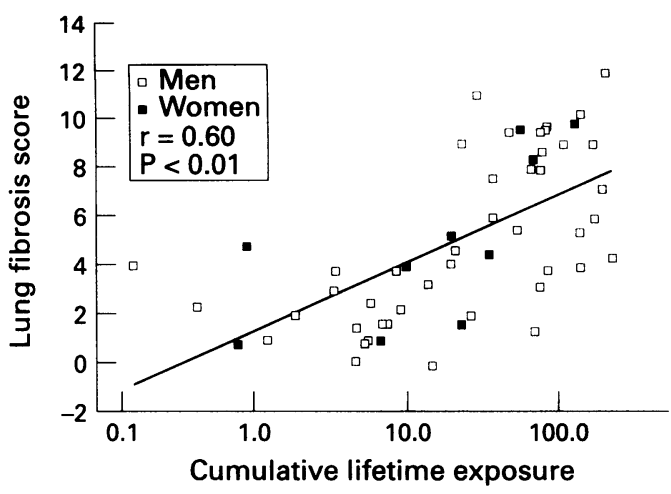

Figure 2 Plot showing relation between cumulative lifetime exposure to asbestos, expressed as fibres $>5 \mu \mathrm{m} / \mathrm{ml}^{3}$ $x$ number of years of exposure, and pulmonary fibrosis score in 54 former asbestos textile workers. $(r=0.60, P<0.01)$

Cumulative lifetime exposure is expressed on a log scale. The P value was based on a test for non-zero slope with linear regression analysis.

fibres in the lung. The regression equation for tremolite was:

fibrosis score $=4.14+2.35$ log (lung tremolite) $(\mathrm{P}<0.001)$

The model based on both chrysotile and tremolite was no better than the model based on tremolite alone $(P=0.36)$, but was better than the model based on chrysotile alone $(\mathrm{P}<$ 0.01 ). Accordingly, it was judged that tremolite concentration provided a better prediction of fibrosis score than did the concentration of chrysotile. The effect of age was additive with no evidence for an interaction. No effect of sex was detected. No relation was found between fibrosis score and non-asbestos fibres (fig 3D). There was a non-significant trend toward greater fibrosis scores with increasing asbestos fibre burdens in the control population. The mean number of asbestos bodies on tissue sections was also strongly associated with grade of lung fibrosis $(P<0.001)$.

\section{LUNG CANCER AND PLEURAL PLAQUES}

The proportion of cases with lung cancer and pleural plaques was greater in the asbestos textile workers than in controls, as determined from the necropsy protocols. Lung cancer was recorded in $18.2 \%$ of the asbestos workers compared with $5.8 \%$ in the controls. Pleural plaques were reported for $31 \%$ of asbestos workers and $3 \%$ of controls.

The 10 asbestos workers with lung cancer had significantly greater cumulative exposures, higher mean fibrosis scores, and more asbestos fibres in their lungs than workers without lung cancer (table 6). Nine of the 10 had a diagnosis of asbestosis made on the original necropsy report compared with 14 of the 45 cases without lung cancer.

\section{Discussion}

This study provides further evidence in human subjects that the number of fibres retained in the lung reflects the cumulative exposure to asbestos in the workplace. ${ }^{2021}$ The relation between lifetime cumulative exposure and lung fibre burden was found for total asbestos fibres, as well as for the individual components of exposure, chrysotile and tremolite. It was not 

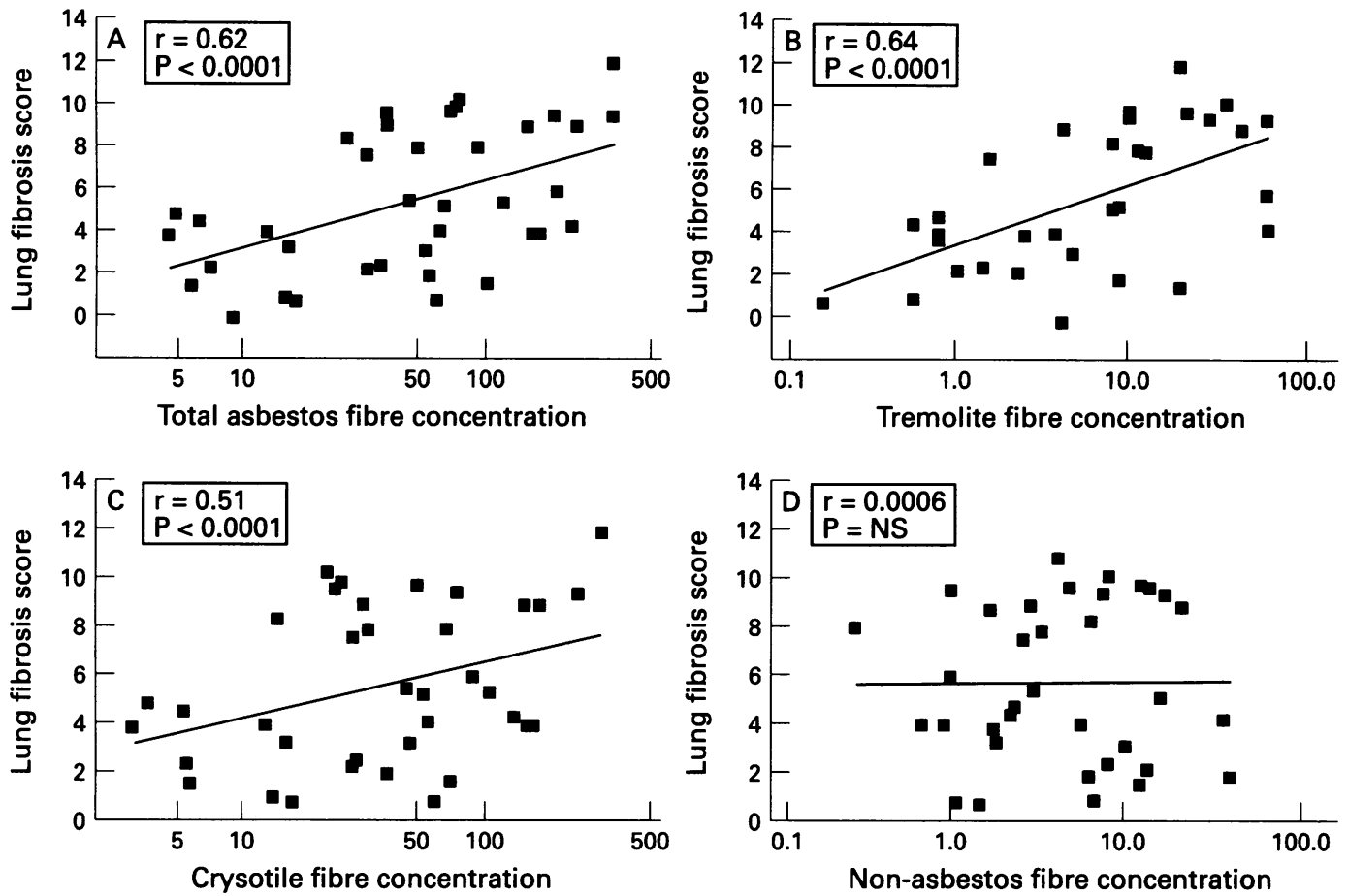

Figure 3 Plot showing relation between lung fibre burden, expressed as log fibres $\times 10^{6} / g$ of dry lung, and pulmonary fibrosis score, for asbestos workers. (A) All potential workplace asbestos fibres (chrysotile + tremolite + crocidolite) $(r=0.62$, $P<0.0001)$. (B) Tremolite $(r=0.64, P<0.0001)$. (C) Chrysotile $(r=0.51, P<0.0001)$. (D) Non-asbestos fibres $(r=$ $0.0006, N S)$. Positive and significant relations are seen for all asbestos fibres as well as for the two major types, chrysotile and tremolite. No relation was noted for non-asbestos fibres (mullite, rutile, iron, and muscovite) indicating that these fibres are non-fibrogenic. The $P$ values were based on tests for non-zero slope with linear regression analysis.

Table 5 Cumulative exposure by quartile and its relation to fibrosis score and concentrations of chrysotile and tremolite in the lung

\begin{tabular}{|c|c|c|c|c|c|c|}
\hline & \multirow[b]{2}{*}{$\begin{array}{l}\text { Cumulative exposure } \\
\text { quartile (fibre-years) }\end{array}$} & \multirow[b]{2}{*}{$n$} & \multirow[b]{2}{*}{$\begin{array}{l}\text { Age at death } \\
\text { (median) }\end{array}$} & \multirow[b]{2}{*}{$\begin{array}{l}\text { Fibrosis score } \\
\text { (median) }\end{array}$} & \multicolumn{2}{|c|}{ Asbestos fibres $\times 10^{6}$ dry lung } \\
\hline & & & & & $\begin{array}{l}\text { Chrysotile } \\
\text { (median) }\end{array}$ & $\begin{array}{l}\text { Tremolite } \\
\text { (median) }\end{array}$ \\
\hline \multicolumn{7}{|c|}{ Asbestos workers: } \\
\hline 1 & $(0.1-7.1)$ & 14 & 46 & 1.8 & 11.4 & 0.5 \\
\hline 2 & $(7.2-36.5)$ & 13 & 55 & $3.3^{\star}$ & $37.6^{\star}$ & $5.0^{\star}$ \\
\hline 3 & $(36.6-109.5)$ & 14 & 61 & $7.9^{\star}$ & $30.8^{\star}$ & $6.4^{\star}$ \\
\hline 4 & $(109.5-370)$ & 14 & 58 & $8.8^{\star}$ & $104.5^{\star}$ & $27.8^{\star}$ \\
\hline Controls & & 14 & 61 & 1 & 7 & 0.3 \\
\hline
\end{tabular}

${ }^{\star} \mathrm{P}<0.05 v$ controls, Wilcoxon rank sum test.

Table 6 Cumulative exposure, fibrosis score, and lung burden of asbestos fibres for asbestos workers with and without lung cancer

\begin{tabular}{|c|c|c|c|c|}
\hline Characteristic & Units & $\begin{array}{l}\text { Lung } \\
\text { cancer }\end{array}$ & $\begin{array}{l}\text { Without } \\
\text { lung } \\
\text { cancer }\end{array}$ & $P$ value* \\
\hline $\begin{array}{l}\text { Number } \\
\text { Lifetime cumulative }\end{array}$ & - & 10 & 43 & - \\
\hline exposure & mean & 94.6 & 21.3 & 0.03 \\
\hline Fibrosis score & mean & 7.7 & 4.7 & 0.01 \\
\hline $\begin{array}{l}\text { Total concentration } \\
\text { of asbestos fibres } \\
\text { in the lung (fibres } \\
\times 10^{6} \mathrm{~g} \text { ) }\end{array}$ & $\begin{array}{l}\text { geometric } \\
\text { mean }\end{array}$ & 61.1 & 41.5 & 0.42 \\
\hline
\end{tabular}

found for other types of asbestos; nor was it found for non-asbestos fibres, indicating that both type and number of fibres in the lung are important in this relation. The study also showed a significant relation between grade of pulmonary fibrosis (asbestosis) and cumulative lifetime exposure to asbestos. Neither the peak exposure nor average exposure had any significant influence on the fibrosis score either inde- pendently or as well as the cumulative effect. Finally, the study showed that lung fibrosis increases with increasing burden of asbestos fibres in the lung. This relation was strongest for tremolite but was also found for total lung asbestos fibres and for chrysotile asbestos. No relation between non-asbestos fibres in the lung and lung fibrosis was found, even though the concentration in the lung of the major nonasbestos mineral mullite was equivalent to that of tremolite (table 3).

Figure 4 shows the relation between the three primary variables; lifetime cumulative exposure, lung asbestos fibre burden, and lung fibrosis. Although there is a clear relation between all three variables, the shape of the three dimensional plot indicates non-linearity and a possible threshold effect. Reanalysis with models with a quadratic term gave similar results to the multiple linear regression analyses but did not contribute additional information.

The findings were made despite several limitations inherent in the study design. Firstly, the 


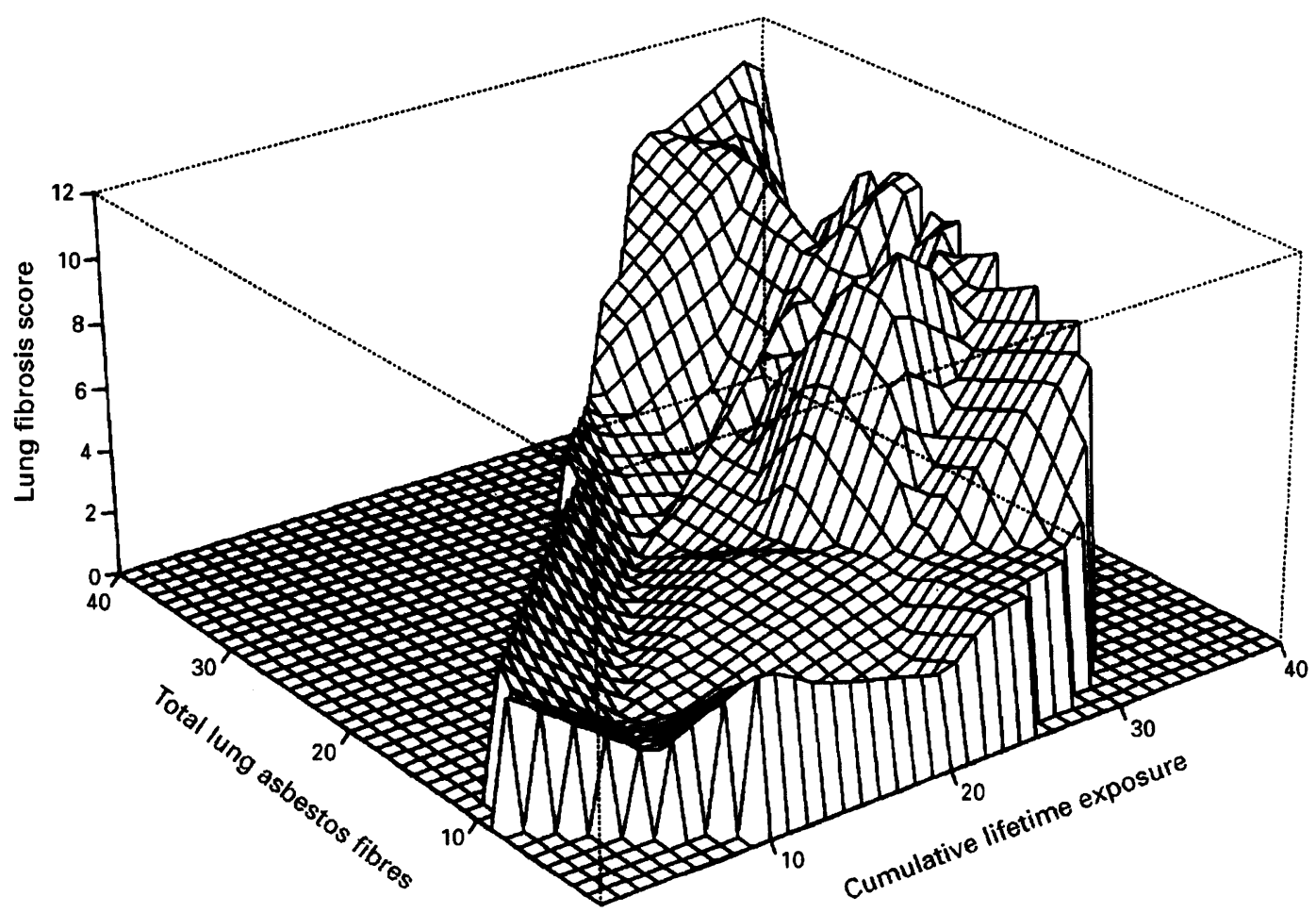

Figure 4 Three dimensional plot showing relation between lifetime cumulative exposure, fibrosis score, and total lung burden of asbestos fibres. Cumulative exposure and asbestos fibre burden are shown on a log scale.

study population was derived from necropsied hospital based patients, many of whom were admitted with diseases unrelated to asbestos exposure. Some of these patients had pulmonary diseases that produce chronic interstitial fibrosis. In these cases, it was impossible to assess the relative contribution of asbestos exposure to the fibrosis, and they were excluded from the study. About equal numbers of patients and controls had confounding diseases. Also, we were not able to control for effects due to selection for necropsy, lung site sampling, or method of lung fixation. These factors, which are largely unavoidable in retrospective necropsy studies, could introduce unknown bias. We were, however, able to control for the possible confounding effect of asbestos contamination at necropsy by taking control samples from the same hospitals. Secondly, smoking and asbestos dust are both known to cause small airways disease ${ }^{102-24}$; and therefore smoking status could have influenced the pathological grade of asbestosis. This effect is likely to be minor. Morphological studies comparing the small airways of asbestos workers who smoked and non-asbestos workers who smoked have shown that the contribution of cigarette smoking to airway fibrosis is small 224 or absent compared with the effect of asbestos exposure. Nor does it contribute to the radiographic category of pneumoconiosis. ${ }^{25}$ Smoking could also influence deposition and retention patterns of asbestos fibres. Churg et $a l^{26}$ have shown that smoking is associated with decreased retention of exogenous non-fibrous mineral particles in the airways compared with non-smokers but that smoking had no effect on parenchymal particle concentration. In a later study of Quebec chrysotile miners and millers, Churg $e t a l^{7}$ found no relation between pack-years of smoking and parenchymal con- centration of asbestos in the lung. It is unlikely that the data on fibre burden were influenced by cigarette smoking in this study as all analyses were made on lung parenchyma.

Although smoking histories were not available on each subject in this study, data from a 1964 Public Health Service survey at the asbestos plant showed that $52.4 \%$ of the male workers were current smokers, $22.3 \%$ were past smokers, and $25.3 \%$ were non-smokers. ${ }^{6}$ These values were similar to those for the adult male population of the United States at the time of the study. ${ }^{6}$ It is unlikely, therefore, that there were significant differences in smoking habits between the study population and the control group from the general population.

The exposure data in this study were the same as those used by Dement et $a l^{l}$ and McDonald et $a l^{4}$ for their mortality studies, where they are discussed in more detail. The high degree of correlation between the exposure estimates and the numbers of asbestos fibres and asbestos bodies in the lung found in this study provides additional evidence for the accuracy of the exposure data. Sebastien $e t a l^{20}$ came to a similar conclusion based on analysis of 30 lungs from the cohort studied by McDonald et al. ${ }^{4}$

The population was exposed almost exclusively to chrysotile asbestos from Quebec. ${ }^{7}$ The native ore contained about $1 \%$ tremolite asbestos. ${ }^{20}{ }^{28}$ The high concentrations of chrysotile and tremolite asbestos found in the lungs of the asbestos textile workers are also consistent with their exposure histories. Our finding on enrichment of tremolite relative to chrysotile in the lungs of asbestos workers is consistent with previous reports. ${ }^{19}{ }^{20}$ The presence of crocidolite in some of the lungs of the asbestos workers is in keeping with the use of small quantities of crocidolite between 1950 and 
1975 , but the values were only slightly greater than those found in the control population.

Because the exposure values in this study are expressed in units used in setting workplace exposure limits, we were particularly interested in finding the minimal exposure necessary to produce a histological lesion consistent with asbestosis. Mean pulmonary fibrosis scores for the asbestos workers in all exposure categories were higher than the control population (table 5), indicating a fibrogenic effect of asbestos at moderately low exposures. The model was not sufficiently precise, however, to determine a minimal or threshold level of exposure that would produce asbestosis. The lack of statistical power in our study was largely due to the small number of cases with low and intermediate levels of exposure. Despite this limitation, analysis of our data on a case by case basis showed that asbestosis of grade 2 severity or more was consistently found in workers with lifetime cumulative exposures in excess of 20 fibre-years and in three cases with exposures ranging from $10-20$ fibre-years. It is noteworthy that exposures in the range of 6.8-27.4 fibre-years were associated with a standardised mortality ratio (SMR) of 1.56 for nonmalignant respiratory disease in a follow up study of 3022 male and female workers from the plant. ${ }^{8}$

In this study we found a positive correlation between total number of asbestos fibres in the lung and severity of pulmonary fibrosis. This finding has been shown in several other necropsy studies of people exposed to asbestos. ${ }^{21} 23^{27} 29-34$ The relation between the different types of asbestos in the lungs and pulmonary fibrosis was reported in some of these studies. ${ }^{21}{ }^{29-32}$ An analysis of lungs from a series of asbestos textile workers from east London exposed to crocidolite, chrysotile, and amosite showed that crocidolite and amosite were strongly associated with severity of asbestosis, whereas no such correlation was evident with chrysotile. ${ }^{21}$ In our study both chrysotile and tremolite were positively associated with grade of pulmonary fibrosis, however the concentration of tremolite in the lung was a better predictor of pulmonary fibrosis than was the chrysotile concentration, a finding also reported by others. ${ }^{32}{ }^{34}$ This relation between amphibole asbestos and lung fibrosis is, however, a statistical one and should not be taken to imply that only amphibole produces the biological response. Chrysotile asbestos fibres fragment into fine fibrils, and are cleared from the lungs more rapidly than amphibole asbestos fibres, ${ }^{32}{ }^{35}{ }^{36}$ thus a component of the lung fibrosis in these asbestos workers could be due to asbestos fibres that were subsequently cleared.

This study does not provide a definitive explanation for the very high risk of lung cancer in this population. Two mortality studies, with similar methods, conducted by $\mathrm{McDonald}$ et $a l^{4}$ and Dement $e t a l^{\beta}$ have shown that the risk of lung cancer, at equivalent levels of exposure, is almost 50 -fold greater in chrysotile textile workers than miners and millers of the chrysotile ore. ${ }^{5}$ These extraordinary differences in mortality could not be explained by differences in smoking habit between the two cohorts. ${ }^{4}$

Errors in exposure estimates for the two workplaces could account for the findings. Sebastien et al tested this hypothesis by analysing lung samples by transmission electron microscopy in 32 paired subjects taken from the cohort of miners and millers from Quebec and from the cohort of asbestos textile workers in Charleston, South Carolina. ${ }^{20}$ The subjects were matched for duration of employment and time from last employment to death and the number and size of fibres, categorised by type of asbestos. In the matched pair analyses, the ratio between mean exposure (mpcf) and mean lung burden of chrysotile for miners and millers as opposed to textile workers were similar at 4.8 and 4.3, respectively. They concluded that the midget impinger measurements adequately reflected exposure to chrysotile in both industries. Furthermore, their data indicated that overall exposure to chrysotile was substantially higher $(x 4)$ in the asbestos mining and milling industry than in the asbestos textile mills.

The increased risk of lung cancer in the asbestos textile workers is also unlikely to be due to differences in exposure to tremolite asbestos, as Sebastien et al have shown that the textile workers had less tremolite asbestos in their lungs than miners and millers of the original ore after matching for exposure intensity. ${ }^{20}$ Differences in exposure to other commercial amphiboles (crocidolite and amosite) may have played a small part based on our own data (table 3) and on the data of Sebastien $e t a l,{ }^{20}$ which showed a small excess of these amphiboles in the lungs of the textile workers compared with the miners. However, it is very unlikely that this is the whole explanation as commercial amphiboles formed a very small proportion of the total amphiboles in both studies. Moreover, review of the 10 cases with lung cancer in this study on whom lung fibre analyses were made, showed only one case with substantially increased $\left(>1 \times 10^{6} \mathrm{fibre} / \mathrm{g}\right.$ dry lung) crocidolite or amosite.

The presence of longer fibres in the textile industry could also provide an explanation for the high mortality from lung cancer and asbestosis in this population. Fibre dimensions are known to play a critical part in asbestos carcinogenicity and fibrogenicity. ${ }^{36}{ }^{37}$ The work of Stanton and colleagues ${ }^{37}$ has shown that relatively long $(>8 \mu \mathrm{m})$ and thin $(<1.5 \mu \mathrm{m})$ fibres are more carcinogenic than shorter and thicker fibres. Sebastien et $a l^{20}$ concluded that differences in fibre dimensions could not explain the higher risk of lung cancer found in the asbestos textile workers. They based this conclusion on the finding that the dimensions of chrysotile and tremolite asbestos fibres extracted from the lungs of asbestos miners and millers and the asbestos textile workers were similar overall. However, they did find a slight excess of very long ( $>20 \mu \mathrm{m})$ chrysotile and tremolite asbestos fibres in the lungs of the textile asbestos workers compared with the miners and millers, a finding that may be 
important. These data indicate that the asbestos textile workers in this study were exposed to longer thinner fibres than other occupational groups working with chrysotile asbestos. In our study, the dimensions of the chrysotile and tremolite fibres in the lungs of the textile workers were considerably longer and had greater aspect ratios than fibres taken from the lungs of the control population.

Although fibre dimensions and clearance kinetics change with fibre type and residence time in the lung, ${ }^{35} 363839$ the data presented here show that the asbestos textile workers had significantly longer chrysotile fibres in their lungs at death than did a demographically similar control group. Our data contrasts with the findings from a study of 76 Swedish asbestos cement workers and 96 controls reported by Albin et al. ${ }^{34}$ The lungs from these cases were analysed in Pooley's laboratory with the same methods reported in this study and contrasted with data obtained from the Charleston asbestos textile workers. ${ }^{19}$ The mean length of 7849 chrysotile asbestos fibres from the Swedish asbestos cement workers was $1.07 \mu \mathrm{m}$ compared with a mean length of $1.19 \mu \mathrm{m}$ from 7630 fibres from the control group. This contrasted with mean lengths of $2.4 \mu \mathrm{m}$ and $0.9 \mu \mathrm{m}$ in the Charleston asbestos textile workers and control group, respectively.

The finding of longer fibres in the lungs of the asbestos textile workers is supported by information on workplace exposures. Dement et $a l^{40}$ analysed historic workplace air samples collected in chrysotile manufacturing industries between 1964 and 1971. By electron microscopy they showed a greater prevalence of long thin fibres in airborne dust samples from textile operations compared with other industrial operations that use chrysotile. Textile fibres were also considerably longer than airborne fibres measured in chrysotile mining and milling operations. ${ }^{41}$

Finally, the impact of asbestos induced fibrosis on the pathogenesis of lung cancer needs to be considered. Several epidemiological studies (reviewed ${ }^{42}$ ) and two necropsy studies ${ }^{43}{ }^{44}$ have shown that the risk for lung cancer in populations exposed to asbestos is greatly increased in the presence of asbestosis. Similarly, animal studies have shown a close association between the fibrogenicity of a dust and its carcinogenicity (reviewed ${ }^{45}$ ). Davis and Cowie $^{45}$ explored this relation further by comparing the fibrosis scores of groups of animals with and without lung tumours exposed to mineral fibres under the same exposure conditions. They found that animals with pulmonary tumours had double the fibrosis of animals that did not. Our finding that nine of 10 of the cases of lung cancer also had asbestosis is in keeping with the epidemiological and experimental studies already discussed.

In conclusion, we have shown that the concentration of asbestos fibres in the lung can provide an accurate reflection of workplace exposure conditions several years or many decades before death. Also, we have shown that both cumulative exposure and lung fibre burden are accurate predictors of biological response (asbestosis). Our results, combined with previous reports, indicate that the dimensions of the airborne fibres in asbestos textile operations provide the most plausible explanation for the high mortality from lung cancer and asbestosis in this population.

We thank the many hospitals and pathologists who contributed material for the study. Technical help was provided by Marilyn Gamble and Artee Karkhanis. Secretarial assistance was provided by Marnie Cudmore.

1 Becklake MR. Asbestos-related diseases of the lung and ther organs: their epidemiology and implications for clinical practice. Am Rev Respir Dis 1976;114:187-227.

2 Selikoff IJ, Hammond EC, Seidman H. Mortality experience of insulation workers in the United States and Canada, 1943-76. Ann NY Acad Sci 1979;330:91-116.

3 Hughes JM, Weill H. Asbestos exposure-quantitative assessment of risk. Am Rev Respir Dis 1986;133:5-13.

4 McDonald AD, Fry JS, Woolley AJ, McDonald JC. Dust exposure and mortality in an American chrysotile textile plant. Br F Ind Med 1983;40:361-7.

5 McDonald JC, Liddell FDK, Gibbs GW, Eyssen GE, McDonald AD. Dust exposure and mortality in chrysotile mining, 1910-75. Br F Ind Med 1980;37:11-24.

6 Dement JM, Harris RL, Symons MJ, Shy CM. Estimates of dose-response for respiratory cancer among chrysotile asbestos textile workers. Ann Occup Hyg 1982;26:869-87.

7 Dement JM, Harris RL, Symons MJ, Shy CM. Exposures and mortality among chrysotile asbestos workers. Part I, and mortality among chrysotile asbestos workers.

8 Dement JM, Brown DP, Okun A. Follow up study of chrysotile asbestos workers: cohort mortality and case-control analysis. Am F Ind Med 1994;26:431-47.

9 Herovici C. A polychrome stain for differentiating precollagen from collagen. Stain Tech 1963;38:205-6

10 Craighead JE, Abraham JL, Churg A, Green FHY, Kleinermen J. Pratt PC, et al. The pathology of asbestos associated diseases of the lungs and pleural cavities: diagnostic criteria and proposed grading schema. Arch Path Lab Med 1982;6: 543-96.

11 Wagner JC, Pooley FD, Berry G. Seal RME, Munday DE, Morgan J, Clark NJ. A pathological and mineralogic study of asbestos-related deaths in the United Kingdom in 1977. Ann Occup Hyg 1982;26:423-31.

12 Pooley FD, Clark NJ. Quantitative assessment of inorganic fibrous particulates in dust samples with an analytical transmission electron microscope. Ann Occup Hyg 1979; 22:253-71.

13 Rogers AJ. Determination of mineral fibre in human lung tissue by light microscopy and transmission electron microscopy. Ann Occup Hyg 1984;28:1-12.

14 Churg A, Wood P. Observations on the distribution of asbestos fibres in human lungs. Environ Res 1983;31:374 80 .

15 Becker RA, Chamber JM, Wilds AR. The NEW S language: a programming environment for data analysis and graphics. Pacific Grove, CA: Wadsworth, 1988.

16 Armitage P, Berry G. Statistical methods in medical research. Oxford: Blackwell, 1987.

17 Green FHY, Attfield M. Pathology standards for asbestosis. Scand $\mathcal{F}$ Work Environ Health 1983;9:162-8.

18 Feinstein AR. Clinical epidemiology: the architecture of clinical research. Philadelphia: WB Saunders, 1985:184-6.

19 Pooley RW, Mitha R. Fibre types, concentrations and characteristics found in lung tissues in chrysotile-exposed cases and controls. In: Wagner JC, ed. Accomplishments in oncology. Philadelphia: JB Lippincott, 1986;1:1-12.

20 Sebastien P, McDonald JC, McDonald AD, Case B, Harley R. Respiratory cancer in chrysotile textile and mining R. Respiratory cancer in chrysotile textile and mining Med 1989;46:180-7.

21 Wagner JC, Newhouse ML, Corrin B, Rossiter CER, Griffiths DM. Correlation between fibre content of the lung and disease in east London asbestos factory workers. $B r \mathcal{F}$ Ind Med 1988;45:305-8.

22 Wright JL, Churg A. Morphology of small airway lesions in patients with asbestos exposure. Hum Pathol 1984;15:68 74.

23 Churg A. Asbestos fibre content of the lungs in patients with and without asbestos airway disease. Am Rev Respir Dis and without asbest

24 Churg A, Wright JL. Small airways disease induced by asbestos and non-asbestos mineral dusts. Chest 1984;85: asbestos

25 Hnizdo E, Sluis-Cremer GK. Effect of tobacco smoking on the presence of asbestosis at postmortem and on the reading of irregular opacities on roentgenograms in asbestos exposed workers. Am Rev Respir Dis 1988;138:1207-12.

26 Churg A, Wright JL, Stevens B, Wiggs B. Mineral particle in the human bronchial mucosa and lung parenchyma. II. Cigarette smokers without emphysema. Exp Lung Res 1992;18:687-714.

27 Churg A, Wright JL, Vedal S. Fibre burden and patterns of asbestos-related disease in chrysotile miners and millers. Am Rev Respir Dis 1993;148:25-31. 
28 Gibbs GW. Qualitative aspects of dust exposure in the Quebec asbestos mining and milling industry. In: Walton WH Inhaled particles III. Old Woking, Surrey: Unwin, 1971: 783-9.

29 Roggli VL, Pratt PC, Brody AR. Asbestos content of lung tissue in asbestos associated diseases: a study of 110 cases. tissue in asbestos associated
$B r \mathcal{F}$ Ind $M e d ~ 1986 ; 43: 18-28$.

30 Wagner JC, Moncrieff CB, Coles R, Griffiths D, Munday D. Correlation between fibre content of the lungs and disease in naval dockyard workers. $B r \mathcal{F}$ Ind Med 1986;43:391-5.

31 Abraham JL, Burnett BR, Rodriguez-Roisin R. Correlated environmental radiologic, physiologic, pathologic and mineralogic analysis in asbestos workers. Am Rev Respir Dis 1982;125:154.

32 Churg A, Wright JL, Depaoli L, Wiggs B. Mineralogic correlates of fibrosis in chrysotile miners and millers. Am Rev Respir Dis 1989;139:891-6.

33 Churg A, Wright J, Wiggs B, Depaoli L. Mineralogic parameters related to amosite asbestos-induced fibrosis in parameters related to amosite asbestos-induced
humans. Am Rev Respir Dis 1990;142:1331-6.

34 Albin M, Johansson L, Pooley FD, Jakobsson K, Attewell R, Mitha R. Mineral fibres, fibrosis and asbestos bodies in lung tissue from deceased asbestos cement workers. $\mathrm{Br} \mathcal{F}$ Ind Med 1990;47:767-74.

35 Davis JMG, Bechett RE, Bolton P, Callings P, Middleton AP. Mass and number of fibres in the pathogenesis of asbestos-related disease in rats. $B r \mathcal{F}$ Cancer 1978;37:67388.

36 Lippmann M. Effects of fibre characteristics on lung deposition, retention and disease. Environ Health Perspect 1990; 88:311-7.
37 Stanton MF, Wrench C. Mechanisms of mesothelioma induction with asbestos and fibrous glass. $\mathcal{F}$ Natl Cancer Inst 1972;48:797-821.

38 Bellman B, Muhle M, Pott F, Konig M, Kloppel M, Spurny $\mathrm{K}$. Persistence of man made mineral fibres (mmmf) and asbestos in rat lungs. Ann Occup Hyg 1987;31:693-709.

39 Gylseth B, Mowe G, Wannag A. Fibre type and concentration in the lungs of workers in an asbestos cement factory. Br F Ind Med 1983;40:375-9.

40 Dement JM, Wallingford KM. Comparison of phase contrast and electron microscopic methods for evaluation of occupational asbestos exposures. Appl Occup Environ Hyg 1990;5:242-7.

41 Gibbs GW, Hwang CY. Dimensions of airborne asbestos fibres. In: JC Wagner, ed. Biological effects of mineral fibres. Lyon: IARC, 1980.

42 Churg A. Neoplastic asbestos-induced diseases. In: Churg A, Green FHY, eds. Pathology of occupational lung disease. New York: Igaku-Shoin, 1988:279-326.

43 Sluis-Cremer GK, Bezuidenhout BN. Relation between asbestosis and bronchial cancer in amphibole asbestos miners. Br F Ind Med 1989;46:537-40.

44 Kipan HM, Lilis R, Suzuki Y, Valciukas JA, Selikoff IJ. Pulmonary fibrosis in asbestos insulation workers with lung cancer. Br $\mathcal{F}$ Ind Med 1987;44:96-100.

45 Davis JMG, Cowie HA. The relationship between fibrosis and cancer in experimental animals exposed to asbestos and other fibres. Environ Health Perspect 1990;88:305-9.

\section{Vancouver style}

All manuscripts submitted to Occup Environ Med should conform to the uniform requirements for manuscripts submitted to biomedical journals (known as the Vancouver style.)

Occup Environ Med, together with many other international biomedical journals, has agreed to accept articles prepared in accordance with the Vancouver style. The style (described in full in the $\mathcal{F A M A}[1]$ ) is intended to standardise requirements for authors, and is the same as in this issue.

References should be numbered consecutively in the order in which they are first mentioned in the text by Arabic numerals on the line in square brackets on each occasion the reference is cited (Manson[1] confirmed other reports[2][3][4][5]). In future references to papers submitted to Occup Environ Med should include: the names of all authors if there are seven or less or, if there are more, the first six followed by et al; the title of journal articles or book chapters; the titles of journals abbreviated according to the style of Index Medicus; and the first and final page numbers of the article or chapter. Titles not in Index Medicus should be given in full.

Examples of common forms of references are:

1 International Committee of Medical Journal Editors. Uniform requirements for manuscripts submitted to biomed journals. FAMA 1993;269:2282-6.

2 Soter NA, Wasserman SI, Austen KF. Cold urticaria release into the circulation of histmaine and eosinophil cheastic factor of anaphylaxis during cold challenge. chemotactic factor of anaphylax.

3 Weinstein L, Swartz MN. Pathogenic properties of invadWeinstein L, Swartz MN. Pathogenic properties of invad-
ing micro-organisms. In: Sodeman WA Jr, Sodeman WA, ing micro-organisms. In: Sodeman WA Jr, Sodeman WA, eds. Pathologic physiology, mechanisms 